\title{
The Two Sir John Fastolfs
}

Author(s): L. W. Vernon Harcourt

Source: Transactions of the Royal Historical Society, Vol. 4 (1910), pp. 47-62

Published by: Cambridge University Press on behalf of the Royal Historical Society Stable URL: http://www.jstor.org/stable/3678384

Accessed: 27-06-2016 03:51 UTC

Your use of the JSTOR archive indicates your acceptance of the Terms \& Conditions of Use, available at

http://about.jstor.org/terms

JSTOR is a not-for-profit service that helps scholars, researchers, and students discover, use, and build upon a wide range of content in a trusted digital archive. We use information technology and tools to increase productivity and facilitate new forms of scholarship. For more information about JSTOR, please contact support@jstor.org.

Cambridge University Press, Royal Historical Society are collaborating with JSTOR to digitize, preserve and extend access to Transactions of the Royal Historical Society 


\section{THE TWO SIR JOHN FASTOLFS}

By the late L. W. VERNON HARCOURT, M.A.

\section{Read March I7, I9I0}

Ir is now several years ago that Mr. James Gairdner wrote an essay on 'The Historical Element in Shakespeare's Falstaff.' Since then many have ventured to gather where he has strawed; only last year, for example, the public were presented with 'The Case of Sir John Fastolf,' by Mr. Duthie. I mention this instance because Mr. Gairdner himself reviewed the book, and therefore if he had by any chance changed his opinions, there was an opportunity for stating the fact, of which he would doubtless have availed himself. We may consequently assume that the views of the two recognised authorities on Falstaff remain unchanged. The other authority is of course the late Mr. Halliwell-Phillipps, who penned a monograph on this subject. ${ }^{1}$

As defined by authority, inimitable Falstaff, ' much as he undoubtedly owed to the rich imagination and incomparable wit of the dramatist, was an embodiment of traditions respecting two distinct historical personages'-to wit, Sir John Oldcastle, Lord Cobham, the Lollard; and Sir John Falstaff, victor of 'The Herrings ' and victim of Patay - traditions largely tinted with prejudice, but... preserving . . . some little details of genuine historic fact, which if they had not been stereotyped by genius would by this time have perished irrevocably.' 2

We need not present the proofs of this authoritative

1 The Character of Sir John Falstaff.

2 Gairdner, Studies in English History, p. 77. 
conclusion; it would be mere waste of time to dish up the old evidences, and ' make cauld kail het again.' Suffice it to recall those little details which genius has stereotyped. Oldcastle was a Lollard, by tradition he was portly; and though Falstaff is the name of Shakespeare's character in print, Oldcastle he was in manuscript, and Oldcastle was the name of his stage prototype. So much for the fat knight's connection with the first historical personage.

Fastolf of Caister by Yarmouth was also perhaps a Lollard; he is said, on non-contemporary evidence, to have passed his boyhood in the household of Thomas Mowbray, Duke of Norfolk; Sir John really owned a Boar's Head Tavern, not in Eastcheap but at Southwark; and though a brave man, he was more than once accused of cowardice. This is Falstaff's connection with the second historical personage.

Now, with these facts before him, the author of "The Case of Sir John Fastolf' rejected the Oldcastle element and propounded the view that Falstaff was none other than Fastolf, and a very lifelike portrait too; Shakespeare, he opined, was in possession of manuscript evidence not now forthcoming. It is only necessary to choose a light subject to ensure weighty consideration for your views; and the 'Athenaeum,' after chiding the author in question for venturing to break a lance with such formidable opponents as Messrs. Gairdner and Phillipps, wrote :- 'We have been impressed by the evidence which Mr. Duthie has adduced. . . His local knowledge has enabled him to discern the possible identity of Shakespeare's old knight of the Castle with the lord of Caister, as well as other circumstances of time and place which demand full consideration.' It would have been far truer criticism to describe the writer as an indiscreet champion of the weakest part of the authoritative case ; for the more the Fastolf element is insisted upon, the evidence being what it is, the more hopelessly illogical and untenable does the authoritative case become.

Oldcastle without a doubt was the original dramatis persona of Shakespeare's 'Henry IV.' Sir John Fastolf of 
Caister in that reign is an anachronism-he only came into historical existence in I4I5. It was suggested that, owing perhaps to Foxe's 'Book of Martyrs,' or to offence being taken by ' personages descended from his title,' Oldcastle's name had to be altered. As one writer has it: 'the poet was putt to make an ignorant shifte by abusing Sir John Falstophe.' The source of these suggestions is obviously Shakespeare himself, who gives an ambiguous explanation in his epilogue to the second part of 'Henry IV' :-' If you be not too much cloyed with fat meat, our humble author will continue the story with Sir John in it, and make you merry with fair Katharine of France; where, for anything I know, Falstaff shall die of a sweat, unless already he be killed with your hard opinions ; for Oldcastle died a martyr, and this is not the man.'

On the other hand, there is neither evidence nor even suggestion that Shakespeare changed his text to suit the change of name. He still lets Prince Henry address his favourite as 'my old lad of the castle': this, and the defective metre of 'Away, good lads, Falstaff sweats to death,' are two only out of many items of evidence directly to the contrary. How then can we account at all for the Fastolf of Caister element? Shall we argue that the dramatist, unequal to depicting Oldcastle from Oldcastle materials and his own imagination, deliberately borrowed very incorrect and prejudiced details from the later life of another man? If such an argument was sound it might help to account for the choice of a new name; but after all it is useless to discuss the bearings of two plays ('Henry IV' and 'Henry VI') in which the hand of the dramatist is unequally employed.

In order to sweep away once and for all these tangled and illogical speculations, which I have called in jest the authoritative case, it would seem sufficient merely to show that there did exist in the reign of Henry IV a well-known man of the name of Sir John Fastolf, who was dead before Fastolf of Caister won his spurs in France. But I have

T.S.-VOL. IV. 
a far fuller and more piquant solution than this to offer the student of history, if only he will bear with me while I unfold my story.

Why did Shakespeare make such a person as Sir John Falstaff, alias Sir John Oldcastle, Lord Cobham, the boon companion of Prince Henry of Monmouth ? Many chronicles agree in stating that Henry $\mathrm{V}$ when he became king put on the new man, thus plainly indicating that his was a madcap youth; but such guarded references to the prince's early indiscretions as we get from these sources could never have inspired the character-painting of Shakespeare's 'Henry IV': the profligate heir to the throne and his graceless companions, these were undoubtedly begotten of one dominating, traditional episode in the life of the prince, namely, the episode of the assault on Chief Justice Gascoigne. This case also has been authoritatively dealt with, and pronounced a fable invented by Sir John Elyot to please Henry VIII.

Here we are confronted with a more difficult and rather important problem. We must begin by telling the story; it is always worth repeating. Sir Thomas Elyot, in I53I, first published it in his book 'The Governor.' 1

'We lacke not of this vertue domisticall examples, I meane of our owne kynges of Englande ; but moste specially one, whiche, in myne oppinion, is to be compared with any that ever was written of in any region or countray.'

This preamble, let me remark, implies that the author is taking his story from a written source. Elyot, however, is no historian, and the fact that he tells a story is not evidence for or against its truth.

The moste renowned prince, Kynge Henry the fifte, late Kynge of Englande, durynge the life of his father was noted to be fierce and of wanton courage It hapned that one of his seruantes whom he well fauored, for felony by hym committed, was arrayned at the Kynge's benche ; wherof he being aduertised

I Ed. Croft, 1880, pp. 60-72. 
and incensed by light persones aboute hym, in furious rage came hastily to the barre, where his seruant stode as a prisoner, and commaunded hym to be ungyued and sette at libertie, where at all men were abasshed, reserued the chiefe iustice, who humbly exhorted the prince to be contented that his seruant mought be ordred accordyng to the auncient lawes of this realme, or if he wolde haue hym saued from the rigour of the lawes, that he shuld optaine, if he moughte, of the kynge, his father, his gracious pardone; wherby no lawe or iustice shulde be derogate. With whiche answere the prince nothynge appeased, but rather more inflamed, endeuored hym selfe to take away his seruant. The iuge consideringe the perilous example and inconuenience that moughte thereby ensue, with a valiant spirite and courage commaunded the prince upon his alegeance to leue the prisoner and departe his waye. With whiche commandment the prince being set all in a fury, all chafed, and in a terrible maner, came up to the place of iugement-men thinkyng that he wolde have slayne the iuge, or haue done to hym some damage; but the iuge sittyng styll, without mouynge, declarynge the maiestie of the kynge's place of iugement, and with an assured and bolde countenance, hadde to the prince these words folowyng: Sir remembre your selfe; I kepe here the place of the King, your soveraigne lorde and father, to whom ye owe double obedience, wherfore, eftsones in his name, I charge you desiste of your wilfulnes and unlawfull entreprise, and from hensforth gyue good example to those whiche hereafter shall be your propre subiectes. And nowe for your contempt and disobedience, go you to the prisone of the Kynge's benche, where unto I committ you ; and remayne ye there prisoner untill the pleasure of the Kyng, your father, be further knowen. With whiche wordes beinge abasshed, and also wondrynge at the meruailous grauitie of that worshipful Justice, the noble prince, layinge his waipon aparte, doinge reuerence, departed and wente to the Kynge's benche as he was commaunded. Wherat his seruants disdainyng, came and shewed to the Kynge all the hole affaire.

Henry IV thereupon makes a pious speech which we need not repeat. Subsequently to Elyot, the historian Hall and one Redman both give a version of this story, but I do not propose to cite either. Warned, however, by experience in another controversy I should perhaps mention 
that Chief Justice Coke, in his 'Third Institute,' refers to the incident and mentions the judge by name, citing Elyot and Holinshed as his authorities. ${ }^{1}$ Another judge (temp. Elizabeth) is also reported as having cited the case, mentioning Gascoigne by name. ${ }^{2}$ We possess at present no contemporary account of the incident, and no account earlier than that of Sir Thomas Elyot.

It will have been observed that while the name of the judge, not stated by Elyot, has now been supplied, we are still left without any clue as to the date of the incident and the names of the prince's associates. These are furnished (if we may accept such evidence) by Shakespeare and other dramatists. The chief associate of the prince in his frolics is Sir John Oldcastle, Lord Cobham, according to the author of 'The Famous Victories of Henry V'; and, as already mentioned, Oldcastle changed to Falstaff according to Shakespeare, who emphasises the change by declaring that ' Oldcastle died a martyr and this is not the man.' As to the lesser associates, and in particular as regards the person who did the deed which provoked Henry's intervention, we learn nothing definite; the names vary, and are clearly as unimportant as they are fictitious. The date of the episode in question is fixed by Shakespeare's context ; it is represented as having happened prior to the Scrope rebellion of 1405 .

This is all the evidence hitherto produced which is worth citing, and I do not imagine that even the youngest historical student would be willing to accept the story on such evidence alone; the credibility of that evidence must be tested in every possible way.

Let us see first of all whether the story is intrinsically credible. Here the discussion of the pros and cons is facilitated by the existence of an essay, published in 1886 in the Transactions of the Royal Historical Society. The

1 P. 225.

2 Crompton, 1594, p. 79: 'Whidden cites a case in the time of Gascoigne ...? 
writer was the late Mr. F. Solly-Flood, Q.C., M.A.Camb., F.R.Hist.S., sometime H.M. Attorney-General at Gibraltar, and author of a work in which ' all the known cases of contempt ... from the time of Magna Charta to the death of Henry V' are dealt with. The essay in question is said to be 'valuable' by the distinguished bibliographer Dr. Gross, and is characterised as 'exhaustive' by the 'Dictionary of National Biography'; it is one of the authorities, already referred to, which condemns the whole story under discussion as a fable. The author's arguments against Elyot's tale on internal evidence are these :

'Now it happens that in Gascoign's time the English language, in which the Chief Justice is described as having addressed the prince, was not used on the bench' 1

One might with as much reason denounce the writer who attributed to Julius Caesar the words 'I came, I saw, I conquered,' on the ground that Caesar knew no English ; moreover, by a very famous statute, passed in the thirty-sixth year of Edward III, it was expressly enacted that judgments were to be delivered in the English tongue and enrolled in Latin.

There was not then, and never had been, neither was there ever for many years afterwards, such a place of custody as the ' prysone of the Kynge's Bench,' neither did the court of King's Bench ever commit to any 'streight prisone ' 2 or to any prison at all. They committed to the personal custody of their own officer, called the marshal, who was always present in the court when sitting, and every such commitment was recorded thus : 'Committitur marescallo.'s

On the contrary, the court of King's Bench always committed to the prison of the King's Bench. The expression 'committitur marescallo' is an abbreviation of the fuller

1 Op. cit. p. 57.

2 These are the words used by Hall.

3 Op. cit. p. 57. 
phrase 'committitur prisone in custodia marescalli' 1 and the prison itself is quite commonly described as the prison of the marshalsea of the King's Bench.'

No instance whatever has yet been found in any ... . rolls or . . . year-books of any committal in penam by the court of King's Bench, in a summary manner, and without indictment, presentment, information, or arraignment for contempt, committed even in its presence, up to a considerable period after the death of Henry IV.

It is always difficult to criticise an unintelligible assertion. How could a court possibly commit for an offence of which it has no information? Can it be argued that a court, say in the reign of Henry III, was not fully informed of a contempt which it had seen committed in its very presence? Is there any distinction in principle between Prince Henry's matter and the following case in the reign of Edward I ?-'And because the Lord Robert Fitzwalter in the presence of the justices threatened the foresters and verderers who had indicted him, he is adjudged to go

1 See Controlment Roll 46, 4 Henry IV, m. 6d., m. II ; and the Controlment Rolls of this and the preceding reign passim.

2 Controlment Roll 2, m. 39: in prisona marescalcie regis coram rege detentus.

Coram Rege Roll, T. 22 Richard II, m. I7d. : Tempore promulgacionis utlagarle predicte et diu antea et postea fuit in prisona dictl nuper regis marescalcie sue banci ipsius nuper regis coram ipso nuper rege in custodia Iohannis Wykes tunc marescalli marescalcie predicte ac in prisona marescalcie domini Henrici nunc regis banci sui coram tpso nunc rege in custodia dicti Iohannis Wykes marescalli regis nunc marescalcie predicte, occasione felonie predicte et adhuc est.

Controlment Roll 44 , r Henry IV, m. I4d.: reddidit se prisone marescalcie domini regis occasione predicta qui committitur marescallo.

Ibid. m. I6: in prisona marescalcie domini regis coram ipso rege existens.

Controlment Roll 46, 4 Henry IV, m. 23d. : et ea occasione prisone marescalcie de banco nostro ad sectam pincernarum nostrorum commissus fuit.

Patent Rolls Calendar, $\mathrm{r}_{3} 83$, p. 278: Appointment of Robert Bracy, warden of the Marshalsea prison of the King's Bench, to provide carts for the carriage of the King's prisoners to divers parts of the realm where the Bench sits. 
to prison and is given a day to appear before the King.' 1 The simplest answer to this particular argument is that it is quite irrelevant. Elyot does not assert that Henry was committed 'in penam'; he is not even stated to have been committed 'ad respondendum'; the committal in fact corresponds exactly with the - ' And because he is a baron, therefore the lord King must be spoken to,' which is so common in the reign of Edward I. It is well known that the baron committed in this last-mentioned way left the court, in mercy as to his property, but a free man; the case was going to end with a disbursement in the Exchequer, secundum modum delicti.

So far as internal evidence is concerned our critic gives us no further assistance, and we must proceed unaided to consider what is said to have occurred, and to compare the story with the legal practice of the period. In the first place, no one seems to have noticed that according to Elyot the prince never went to prison at all-he merely went to the 'King's Bench.' What the exact practice was I cannot say for certain: going to the King's Bench was a symbolic act, signifying submission to the jurisdiction, and it may have meant going to a certain slab of marble in Westminster Hall known by that name. It is true that this symbolic act was commonly entered on the plea-rolls as 'reddidit se prisone'; but it is absolutely certain that this meant nothing similar to going to prison; the Earl of Warwick, for instance, in high favour with Henry IV, ' rendered himself to prison' early in the reign for the purpose of having a judgment against himself reversed for error. ${ }^{2}$ It would be absurd to suggest that the Earl went to prison in the ordinary sense of the word.

Having related this act of submission by the prince Elyot's story goes off at a tangent. Assuming the story true it was scarcely worth recounting how the incident of committal actually closed, the practice was so well settled

1 Exchequer, Treasury of Receipt, Forest Proceedings, 12, m. 6d.

2 Coram Rege Roll, E. I Henry IV, m. 8d. 
and so unsensational. The prince would have been instantly reconducted before the Chief Justice by the marshal ; and even if his rank had been less than it was, he would, judging by precedent, have been allowed to depart sine die and unconditionally. ${ }^{1}$ Such is the internal evidence. It will be enough to say by way of comment that the story, as told by Elyot, is a much safer guide to the practice of the King's Bench at the time than any of its critics.

The extrinsic evidence against the story is twofold: (i) No extant contemporary chronicler relates the tale; (ii) the committal is not entered on the plea rolls of the court.

Upon the first point it seems necessary to say no more than this: chroniclers relate how Henry on his accession became a changed man, but not a single one of his pranks is related, though he must clearly have committed many follies quite as serious as the one in question if these hints of an amended life are at all justifiable. Moreover, if the story is true, ex hypothesi someone chronicled it, while of his other follies no record remains.

In support of the second point, we are told that the records of the King's Bench have been twice searched by independent inquirers with a view to setting the matter at rest ; in fact, this argument $a$ silentio is put very forcibly by the same learned counsel whose criticisms are quoted above. He says this: ${ }^{2}$

... Lord Campbell, when he ventured to enter the lists against Mr. Tyler, must have known what every member of the legal profession knows, that there are two great rolls of the court, on both of which such an event as the committal of any man by the court for contempt or any other offence could not possibly have failed to be recorded. These rolls are the Rotuli Coram Rege and Controlment Rolls. ... They are extant

1 The following is common practice according to the rolls: ' reddidit se prisone, qui committitur marescallo, et statim per marescallum ductus venit et petit a prisona domini regis deliberari, et quia . . . Consideratum est quod est ad praesens sine die.'

2 op. cit. p. 146. 
for the whole of the reign of Henry IV, without the loss of a single membrane or part of a membrane. On each of these rolls every commitment either ad respondendum or in penam for any offence or cause whatever, made by the court of King's Bench, is to be seen. But not the slightest trace of the commitment of the prince, or of the commitment of any person whatever for any such offence as that attributed to the prince has, after a most careful, diligent, and exhaustive search through all the rolls for the whole of the reign of Henry IV, made by the present writer himself in person, been discovered on any roll or record whatever. The non-existence of any record of a commitment of the prince will be conclusive to the mind of everyone conversant with legal procedure that the story of his misconduct in court and imprisonment is absolutely untrue. . . .

'Exhaustive search' evidently means different things to different persons; so it is desirable to point out that such search, in this case, was insufficient to inform the searcher that the King's Bench were wont to commit to prison; did not apparently reveal the fact that the Baga de Secretis, or Privy Bag, was in constant use, which discovery alone would have necessitated some modification of the quite untrue statement that every commitment is entered on both these rolls; and did not even disclose the circumstance that five, or more than one-third, of the Controlment Rolls for this reign are missing.

With regard to the Baga, it should be pointed out that, assuming some record would have been made of the prince's contempt, it would have been entered on a slip of parchment and filed in the Privy Bag; no mention of it would appear on any roll, unless the matter was further proceeded with. It was, moreover, the common practice to deal summarily with certain committals for contempt, without recording either the contempt or the committal. This I am going to prove.

A second, independent search of the Controlment Rolls was instituted by the latest editor of 'The Governor' a few years after the first. ' It is certain,' this writer observes in a note, "from the previous condition of these rolls that 
no writer in the present century has ventured upon such a method of verification.' I I need only repeat that, for the purpose of proving a negative, this method is extremely defective.

I will now tender in evidence the story of a gross contempt of court, committed some time prior to the Scrope rebellion of 1405 . The story begins a score of years earlier, and very prosaically with the following uncancelled entry on the Close Roll for 3 Richard II, m. Iod:

Hugh Fastolf and John Organ, citizens of London, acknowledge that they owe to John de Cobham, lord Cobham, 800 marks, to be paid to him at the feast of Pentecost next; and, unless they do so, they concede that the aforesaid moneys shall be raised from their lands and chattels in London, and in the counties of Essex, Norfolk and Suffolk, and elsewhere. Witness the King at Westminster, the 28th day of March.

The next incident in the story is thus entered up in the Coram Rege Roll for Hilary, 4 Henry IV, m. 25 :

The jury, between John de Cobham, lord Cobham, by his attorney, plaintiff, and John Fastolf, knight, son and heir of Hugh Fastolf late citizen of London, summoned to find, etc., whether the aforesaid John Fastolf, on the 3rd day of December in the first year of the reign of our present lord King, or at any time afterwards, held the manors of Bradwell, Olton and Kyrkele with their appurtenances in the county aforesaid, which belonged to the aforesaid Hugh after the 28th day of March in the 3rd year of the reign of our lord King Richard, late King of England the second after the conquest, on which day the said Hugh Fastolf and John Organ, then citizens of London, now deceased, in the chancery of the same late King, acknowledged that they owed to the aforesaid John de Cobham 800 marks, as it is alleged, or no, is respited before the lord King until fifteen days from Easter day, wherever, etc., owing to the default of jurors because none, etc. Therefore let the sheriff have their bodies etc., and eight such are appointed, etc. The same day is given to the parties aforesaid. 
Now, as a matter of fact, a serious contempt had been perpetrated, although no inkling of this appears in the roll. Sir John Fastolf, or someone on his behalf, had prevented the jury from giving their verdict. What exactly took place we are not told; but there appears to have been a brawl, ending in some of the jurors being hounded out of court; at all events Fastolf was committed and his contempt was summarily dealt with, as reported below from the Rex Roll, m. I8, for the same term, and the Controlment Roll, 4 Henry IV, m. I3d:

(England.) Memorandum that on Thursday next before the quindene of Hilary in this same term before the lord King at Westminster came Adam Cliston, knight, of the county of Norfolk, William Calthorp, knight, of the same county, John Wilton, knight, of the same county, and John Norwich of the county of Suffolk, in their own persons, and mainperned for John Fastolf, knight, then present in court, that he would thenceforth be of good behaviour towards the lord King and all his . people, and especially towards twelve jurors impanelled and on the said quindene sworn before the King [in the suit] between John lord Cobham, plaintiff, and the said John Fastolf, defendant, upon a certain acknowledgement of 800 marks made in the Chancery of the lord King, as more fully appears by the record before the said King, that the same John Fastolf will not do or cause to be done, by himself or others, to the same jurors or any of them or any of the people of the lord King, damage or bodily hurt, by threats, assaults, insults, or any other means which might in any manner tend to a lesion or disturbance of the peace of the lord King, each of the mainpernors under penalty of 20ol., and the said John Fastolf, under penalty of $500 l$., which 200l., each of the said mainpernors by himself, and which 50ol. the said John Fastolf, acknowledged that they owed to the lord King to be raised out of the lands and chattels of them and each of them to the King's use according to the mainprise aforesaid, if the said John Fastolf should make default in the premises or any of the premises and therefore be lawfully convicted.

The above-named parties are Sir John Fastolf of Nacton, or Cowhawe in Nacton, who flourished and died in the 
reign of Henry IV ; and Sir John, Lord Cobham, the fatherin-law of Sir John Oldcastle, Lord Cobham.

The circumstances of this contempt of court, and the conjunction of these two names seem altogether too extraordinary for a mere coincidence. It is now, to say the least, quite probable that Elyot was telling a true story, but, owing to the King's Bench practice of not enrolling either contempt or committal in cases of this kind, we are left to conjecture what happened. Here, then, let us suggest, is quite a gentlemanly brawl in the court of King's Bench : Prince Henry and Fastolf have brought off a joke against an old friend of the King; Nym, Poins, and Bardolf, their servants, fictitious names but real persons, have with Irish gaiety done a little jury-driving in Westminster Hall ; Bardolf is caught by the ushers and dragged before the Chief Justice. Everyone in court is tittering, Gascoigne is furious. One can imagine him exclaiming 'Let a jury be impanelled instanter-this rogue shall hang.' Then the prince gets angry and the regrettable incident occurs. After the dramatic, aye, and princely act of submission, Fastolf sees a way out of the business; he comes forward and confesses to being responsible for Bardolf's contempt, factum illud bene advocavit as the court remembrancer would say; whereupon he is committed and bound over to keep the peace in manner recounted, and thus the matter terminates.

Now that the ground has been cleared and these fresh facts brought to light, it is quite likely that still further evidence will soon be forthcoming which will completely establish Elyot's story; but it is worth raising the question on the evidence as it stands, whether historians should accept or reject the account of Prince Henry's committal. We may surmise that Mr. Wylie for one would accept the story. If I interpret him aright he was prepared to accept it when he wrote his 'History of Henry IV,' subject to the assumption that the prince's imprisonment was merely nominal, and I have fully justified that assumption. On 
the other hand, it is probable that many historians will still reject the story. Which view is right? The problem turns upon the admissibility of non-contemporary evidence.

The following rules for the admission or rejection of non-contemporary evidence commend themselves to the present writer.

I. Non-contemporary evidence of a fact is excluded by contemporary evidence of the fact.

2. More remote non-contemporary evidence of a fact is excluded by less remote evidence of the fact.

3. Subject to the foregoing rules, non-contemporary evidence of a fact is admissible in the following circumstances :

(i) It is intrinsically credible, and-

(ii) It is consistent with all extant contemporary evidence, and-

(iii) It is corroborated in some material particular by contemporary evidence, or-

(iv) There is credible evidence that the non-contemporary statement comes from a contemporary source.

These rules would obviously require elaboration to meet special cases; but as applicable to all ordinary cases they ought, I think, to commend themselves to every historian.

Let us summarise the argument and apply these rules.

The story of Prince Henry's committal is quite credible judged by internal evidence. Moreover, we have the following extrinsic evidence: (Non-contemporary) One of Henry's associates gets into a scrape in the King's Bench, and the prince intervenes [Elyot]; Henry's chief associate in his pranks is Sir John Fastolf, called Sir John Oldcastle Lord Cobham by mistake, and the event in question occurs before I405 [Shakespeare]. (Contemporary) Sir John Fastolf did get into a serious scrape, before I405, in the King's Bench, over a case to which a John Lord Cobham was party [original records of the King's Bench]. 
Elyot's story taken by itself clearly survives rules I, 2, and 3, i. As regards rule 3, ii, there is, so far as is known, no inconsistent contemporary evidence. Prince Henry may well have been in London at the time. His household was at Kempton from the end of November to January 6, I402-3; by January 29 it had been removed to Kenilworth; in the interval his harness and effects are being carted from Kempton and London.' Rule 3, iii, is the difficulty. Elyot is not actually corroborated by any contemporary evidence until we admit the additional details furnished by Shakespeare, but of these there is no corroboration independent of Elyot's story. It might be suggested that rule 2 excludes even the additional details furnished by Shakespeare; this, I think, would be placing too strict an interpretation on the rule; on the contrary, it would be allowing too loose an interpretation to admit these additional details without requiring independent corroboration. In other words, if they cannot be admitted at all except as distinct facts, they must be corroborated as such. The story therefore of Prince Henry's committal is not strictly proved, and historians are justified in not accepting it until further evidence is forthcoming. Conversely, the story is highly probable, and there is no justification for describing it as untrue.

This conclusion is disappointing but not irrevocable, and some useful results have been achieved by the present inquiry. The Falstaff case no longer stands where it did. If the stage knight was really meant for Fastolf, then we have a far more plausible solution to offer than any which has yet been put forward. Sir John of Caister is dismissed as an interloper, Sir John of Nacton is the man. Finally, some much needed scavenging has been effected in a popular corner of English history.

1 Exchequer Accounts, 404, file 23. 